\title{
Markl warns Germany not to reduce budget increase
}

[DORTMUnd, GERMANY] Hubert Markl, the president of the Max Planck Society (MPS), has warned Germany's federal and regional governments to expect fierce protests if they try to back down on a promise to increase the organization's budget for 2000 by five per cent.

Finance ministers of the German Länder (states) recently proposed that this increase — which would cost DM95 million (US\$51 million) next year — should be reduced to only two per cent, or DM38 million (see Nature 399,$508 ; 1999)$. They say this is due to the continuing problems in the German economy and the need to cut back on public spending.

But Markl told the annual assembly of the MPS in Dortmund last week that, if such a cut were to be made, the extra money in next year's science budget would be totally absorbed by salary increases, and that "in real terms our budget would shrink".

He pointed out that Rita Colwell, the director of the US National Science Foundation, had said that her agency was expecting an increase of up to 25 per cent next year, and he urged Chancellor Gerhard Schröder and Edelgard Bulmahn, the federal science minister, not to break their "plain promises" - a reference to a pre-election pledge to maintain the funding increases promised by the previous government. Otherwise, he warned, the competitiveness of cutting-edge science in Germany would be seriously weakened.

Markl also warned that if the finance ministers' proposals were accepted, institutes in east Germany would suffer most. Since 1991, annual budget increases have allowed the MPS to set up 19 institutes in the five new Länder, and most of the scientific directors for them have now been appointed.

"If we have to back out just before regular scientific work starts, it would end up in very hard and embarrassing cancellations of appointments," said Markl.

Markl argued that the new financial constraints on basic research are the result of misguided political decisions and priorities. He pointed out, for example, that Germany's 40 per cent contribution to the European component of the International Space Station had been agreed "against the advice of many experts".

"Science did not want a project that would eat up more than $\$ 100$ million," Markl said. He argued that Germany's "political decision" to contribute to the space station should not be financed by cuts in the basic science budgets.

In his speech, Markl also emphasized

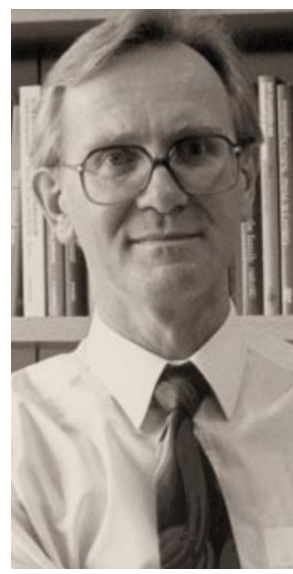

that the MPS was keen to implement changes recommended last month by an external evaluation committee (see Nature 399, 395-396; 1999), as he conceded that the society had occasionally neglected modern research needs through "selfdeception" and "insufficient public relations".

At the same time,

Markl: east Germany would be hit hardest.

he warned society members not to act too hastily, and he said that all recommendations should be carefully considered over the next six months. Wolf Singer, director of the Frankfurt-based Institute for Brain Research, has been chosen to head a committee that will draft proposals for reform by the autumn.

The MPS has already taken up one recommendation: to improve career opportunities for women. At present, there are only five women among the 241 directors holding top research (C4) positions. Over the next three years, 15 additional $\mathrm{C} 4$ positions are to be created exclusively for women.

"We will start to actively look for female candidates, even though we are aware of possible legal conflicts over discrimination against men," said Markl.

This programme was approved by the MPS's senate provided that the five per cent increase in the budget - which the evaluation committee also recommended — was not cut.

Markl has sent protest letters to the prime ministers of the 16 Länder - which will make the final decision on the MPS budget - and to the Bund-Länder Kommission, the body that coordinates regional and federal research policies.

Jörn Brand, head of the Bund-Länder Kommission's research funding department, says the finance ministers' stance will be difficult to shift. "It is no longer justifiable that the MPS should be treated so much better than the national research centres or bluechip institutes," he says.

But Brand is confident that the federal government will recommend a compromise proposal increasing the budget by around three per cent. The MPS should then be able "to live with what is still an increase", he says. QuirinSchiermeier
Referee quits journal over price rise as library faces cutbacks

[PARIS] A physicist at Florida State University has resigned as an unpaid referee for a nuclear physics journal published by Elsevier Science in protest at inflation in the price of the company's journals. His home institution supports his decision.

Mark Riley says he was "upset" at cutbacks in journal subscriptions at his university. Its library, like many worldwide, has faced annual inflation in journal prices of around 20 per cent over the past decade. As a result it has cancelled some 2,000 titles and plans to cut a further $\$ 800,000$ worth of journals over the next three years.

In a letter of resignation to Jeanette Bakker, executive editor of Nuclear Physics A - which costs $\$ 7,234$ a year - Riley wrote:

"I am dismayed by the pricing and inflation policies of Elsevier and the significant part they have played, and are playing, in the present journal budget crisis." He adds: "While I respect the quality of Nuclear Physics $A$ as a scientific journal, I feel honour bound to minimize my involvement with Elsevier Publishing at this time."

Riley says that other referees "should think about what they are doing in refereeing for expensive journals, and remember that the serials crisis is affecting their home institutions".

Charles Miller, dean of libraries at the university, applauds Riley's decision. Miller says that journal subscriptions account for 75 per cent of the libraries' spending, and that around 25 per cent of this is on Elsevier Science journals.

"We want to go all-electronic, delivering journals to the desktop and phasing out print altogether," says Miller. But he says this shift is hampered by reluctance on the part of Elsevier Science to dissociate paper and electronic access in its pricing policies.

A new contract with the company has brought down prices, and Miller speaks of "a willingness on Elsevier's part to bring them down further". The university is demanding that Elsevier provide electroniconly access to all its journals at a 30-40 per cent discount on current prices. So far Elsevier has offered 10 per cent, Miller says.

He warns that the university may cancel expensive journals even if these are in heavy demand by users. "They don't believe we will cancel, but we will."

Elsevier Science was unavailable for comment. But Geert Noorman, managing director of its Life Sciences Division, recently told Nature that web publishing is putting pressure on publishers: "If the web causes us to have to agree to lower profit margins, then so be it."
Declan Butler 